\title{
Long-Term Antidepressant Treatments Result in a Tonic Activation of Forebrain 5- $\mathrm{HT}_{1 \mathrm{~A}}$ Receptors
}

\author{
Nasser Haddjeri, Pierre Blier, and Claude de Montigny \\ Neurobiological Psychiatry Unit, McGill University, Montréal, Québec, Canada H3A 1A1
}

\begin{abstract}
We report here the first direct functional evidence of an increase in the tonic activation of postsynaptic 5- $\mathrm{HT}_{1 \mathrm{~A}}$ receptors by antidepressant treatments. Because $5-\mathrm{HT}_{1 \mathrm{~A}}$ receptor activation hyperpolarizes and inhibits $\mathrm{CA}_{3}$ pyramidal neurons in the dorsal hippocampus, we determined, using in vivo extracellular recording, whether the selective $5-\mathrm{HT}_{1 \mathrm{~A}}$ receptor antagonist WAY 100635 could disinhibit these neurons. Unexpectedly, no disinhibition could be detected in controls. However, after long-term treatment with the tricyclic antidepressant imipramine, the selective $5-\mathrm{HT}$ reuptake inhibitor paroxetine, the reversible monoamine oxidase-A inhibitor befloxatone, the $\alpha_{2}$ adrenergic antagonist mirtazapine, or the 5- $\mathrm{HT}_{1 \mathrm{~A}}$ receptor agonist gepirone or multiple electroconvulsive shock (ECS) ad-
\end{abstract}

ministration, WAY 100635 markedly increased (60-200\%) the firing activity of $\mathrm{CA}_{3}$ pyramidal neurons. Such a disinhibition was absent in rats treated with the nonantidepressant drug chlorpromazine, in rats receiving only one ECS, or in rats receiving multiple ECSs in combination with an intrahippocampal pertussis toxin treatment to inactivate $\mathrm{G}_{\mathrm{i} / \mathrm{o}}$-coupled $5-\mathrm{HT}_{1 \mathrm{~A}}$ receptors. These data indicate that such antidepressant treatments, acting on entirely different primary targets, might alleviate depression by enhancing the tonic activation of forebrain postsynaptic $5-\mathrm{HT}_{1 \mathrm{~A}}$ receptors.

Key words: antidepressants; serotonin (5-HT); 5-HT ${ }_{1 A}$ receptors; WAY 100635; disinhibition; dorsal hippocampus
With a prevalence of at least $4 \%$ of the general population, major depression is one of the most common psychiatric disorders. Although its physiopathology is not fully defined, there is a growing body of evidence supporting the implication of the serotonin (5-HT) system in the therapeutic effect of antidepressant treatments (Heninger and Charney, 1987; Price et al., 1990; Van Praag et al., 1990; Cummings, 1993; Blier and de Montigny, 1994; Maes and Meltzer, 1995). Accordingly, it has been shown that long-term tricyclic antidepressant (TCA) and repeated electroconvulsive shock (ECS) administration lead to an enhanced 5-HT neurotransmission through a progressive sensitization of the postsynaptic $5-\mathrm{HT}_{1 \mathrm{~A}}$ receptors in the dorsal hippocampus (de Montigny and Aghajanian, 1978; de Montigny, 1984; Welner et al., 1989; Nowak and Dulinski, 1991; Stockmeier et al., 1992; Burnet et al., 1994). Long-term treatments with monoamine oxidase inhibitors (MAOIs) and selective 5-HT reuptake inhibitors (SSRIs) desensitize the somatodendritic $5-\mathrm{HT}_{1 \mathrm{~A}}$ autoreceptors of 5-HT neurons in the dorsal raphe nucleus, thereby allowing their firing rate to recover in the presence of the drugs (Blier and Montigny, 1985; Chaput et al., 1988). In addition, longterm SSRI treatment desensitizes terminal 5- $\mathrm{HT}_{1 \mathrm{~B} / 1 \mathrm{D}}$ autoreceptors, whereas long-term MAOI treatment desensitizes $\alpha_{2}$ adrenoceptors that are located on 5-HT terminals and inhibit 5-HT release (Blier and Bouchard, 1994; Mongeau et al., 1994). Long-term treatment with the antidepressant mirtazapine, an

Received Aug. 3, 1998; revised Sept. 2, 1998; accepted Sept. 15, 1998.

This work was supported in part by Medical Research Council of Canada (MRC) Grants (MT-11014 and MA-6444 to P.B. and C.dM., respectively), a fellowship from the Fonds de la Recherche en Santé du Québec and the Royal Victoria Hospital Research Institute to N.H., and an MRC Scientist Award to P.B. We thank J.-C. Béique for friendly advice throughout this work.

Correspondence should be addressed to Dr. Nasser Haddjeri, Neurobiological Psychiatry Unit, McGill University, 1033 Pine Avenue West, Montréal, Québec, Canada H3A 1A1.

Copyright (C) 1998 Society for Neuroscience $\quad 0270-6474 / 98 / 1810150-07 \$ 05.00 / 0$ $\alpha_{2}$-adrenoceptor antagonist, increases 5-HT neurotransmission as a result of a sustained increase in 5-HT neuron firing activity in the presence of decreased function of $\alpha_{2}$-adrenoceptors located on 5-HT terminals in the dorsal hippocampus (Haddjeri et al., 1997). Finally, a long-term treatment with 5- $\mathrm{HT}_{1 \mathrm{~A}}$ receptor agonist, such as gepirone, desensitizes the presynaptic $5-\mathrm{HT}_{1 \mathrm{~A}}$ receptors on 5-HT neuron somata but not the postsynaptic 5-HT $1 \mathrm{~A}$ receptors on $\mathrm{CA}_{3}$ pyramidal neurons (Blier and de Montigny, 1987). Consequently, it was hypothesized that in the presence of the exogenous $5-\mathrm{HT}_{1 \mathrm{~A}}$ receptor agonist and a normalized release of endogenous 5-HT, long-term treatment with a 5- $\mathrm{HT}_{1 \mathrm{~A}}$ receptor agonist also leads to an enhanced 5-HT neurotransmission. Together, these data indicate that adaptive changes in the 5-HT system may play a pivotal role in the therapeutic effect of antidepressant treatments. Although in vivo microdialysis studies have shown that long-term antidepressant treatments increase extracellular 5-HT levels in several brain structures including the hippocampus (Bel and Artigas, 1993; Yoshioka et al., 1995), direct functional evidence of an enhanced tonic activation of postsynaptic $5-\mathrm{HT}_{1 \mathrm{~A}}$ receptors induced by long-term antidepressant treatments is not yet available.

In the present study, several classes of antidepressant treatments were studied to determine whether their long-term administration could indeed modify the degree of tonic activation of postsynaptic $5-\mathrm{HT}_{1 \mathrm{~A}}$ receptors on dorsal hippocampus $\mathrm{CA}_{3}$ pyramidal neurons. Because the activation serotonin $_{1 \mathrm{~A}}$ receptors hyperpolarize $\mathrm{CA}_{3}$ pyramidal neurons, the degree of disinhibition induced by intravenous administration of the potent and selective $5-\mathrm{HT}_{1 \mathrm{~A}}$ receptor antagonist WAY 100635 was measured as an index of the tonic activation of postsynaptic $5-\mathrm{HT}_{1 \mathrm{~A}}$ receptors.

\section{MATERIALS AND METHODS}

Treatments. The experiments were performed in vivo in male Sprague Dawley rats. Six groups of rats were treated for $21 \mathrm{~d}$ with imipramine 
(Ciba-Geigy, Montréal, Canada; $10 \mathrm{mg} \cdot \mathrm{kg}^{-1} \cdot \mathrm{d}^{-1}$ ), chlorpromazine (Rhone-Poulenc, Montréal, Canada; $10 \mathrm{mg} \cdot \mathrm{kg}^{-1} \cdot \mathrm{d}^{-1}$ ), befloxatone (Synthelabo Recherche, Rueil-Malmaison, France; $0.75 \mathrm{mg} \cdot \mathrm{kg}^{-1} \cdot \mathrm{d}^{-1}$ ), mirtazapine (Organon, Oss, The Netherlands; $5 \mathrm{mg} \cdot \mathrm{kg}^{-1} \cdot \mathrm{d}^{-1}$ ), paroxetine (SmithKline Beecham, Harlow, England; $10 \mathrm{mg} \cdot \mathrm{kg}^{-1} \cdot \mathrm{d}^{-1}$ ), or vehicle (50\% ethanol-water solution) delivered by osmotic minipumps (Alza, Palo Alto, CA) inserted subcutaneously. One group of rats was treated with gepirone (Bristol-Myers Squib, Wallingford, CT; 15 $\mathrm{mg} \cdot \mathrm{kg}^{-1} \cdot \mathrm{d}^{-1}$, solubilized in water) for 2 weeks. One other group was administered one ECS (150 V pulses of $10 \mathrm{msec}$ duration delivered at a frequency of $50 \mathrm{~Hz}$ for $1 \mathrm{sec}$ ), and another group was given a series of seven ECSs (7-ECS) every other day for $14 \mathrm{~d}$. Finally, one group of rats was treated with pertussis toxin (Sigma, St. Louis, MO), which inactivates $G_{i / o}$-proteins, and one last group was given both seven ECSs and a pertussis treatment. Pertussis toxin, $1 \mu \mathrm{g}$ in $2 \mu \mathrm{l}$, was injected (at a rate of $0.4 \mu \mathrm{l} / \mathrm{min}$ ) unilaterally in the dorsal hippocampus (anterior $=4.2$, lateral $=4.2$, ventral $=3.5) 10 \mathrm{~d}$ before the electrophysiological experiment (Blier et al., 1993). The rats were tested after the long-term treatments with the minipumps in place to mimic clinical conditions, because patients undergo an improvement of their depressive condition while taking their medication and not after withdrawal. In fact, patients often rapidly relapse if their medication is stopped immediately after remission. The animals were anesthetized with chloral hydrate (400 $\mathrm{mg} / \mathrm{kg}$, i.p.), with supplemental doses given to maintain constant anesthesia and to prevent any nociceptive reaction to a tail pinch.

Electrophysiological experiments. Recording and microiontophoresis were performed with five-barreled glass micropipettes prepared in a conventional manner (Haigler and Aghajanian, 1974). The central barrel was filled with a $2 \mathrm{M} \mathrm{NaCl}$ solution and used for extracellular unitary recordings. The pyramidal neurons were identified by their large amplitude (0.5-1.2 mV) and long-duration (0.8-1.2 msec), simple spikes alternating with complex spike discharges (Kandel and Spencer, 1961). The side barrels contained the following solutions: 5-HT creatinine sulfate (Sigma; 2 and $20 \mathrm{~mm}$ in $200 \mathrm{~mm} \mathrm{NaCl}$, pH 4), quisqualate (Sigma; $1.5 \mathrm{~mm}$ in $200 \mathrm{~mm} \mathrm{NaCl}, \mathrm{pH} 8$ ), and $2 \mathrm{M} \mathrm{NaCl}$ used for automatic current balancing. The rats, control or treated with the minipumps in place, were mounted on a stereotaxic apparatus, and the microelectrodes were lowered at $4.2 \mathrm{~mm}$ lateral and 4.2 anterior to lambda into the $\mathrm{CA}_{3}$ region of the dorsal hippocampus. Because most hippocampus pyramidal neurons are not spontaneously active under chloral hydrate anesthesia, a leak or a small ejection current of quisqualate $(+1$ to $-6 \mathrm{nA})$ was used to activate them within their physiological firing range (Ranck, 1975). Neuronal responsiveness to the microiontophoretic application of 5-HT was assessed by determining the number of spikes suppressed for applications of 5-HT (10 nA) and for a duration of $50 \mathrm{sec}$. This corresponds to the number of spikes due minus the number of spikes found with a baseline of firing recorded with a cumulative interval frequency of a duration of $40 \mathrm{sec}$ before the application of 5-HT. The same current of ejection of 5-HT was always used before and after the intravenous injection of the selective $5-\mathrm{HT}_{1 \mathrm{~A}}$ receptor antagonist WAY 100635 (Wyeth Research, Berkshire, UK; $100 \mu \mathrm{g} / \mathrm{kg}$ ). Two minutes before the intravenous administration of WAY 100635, the firing activity of the quisqualate-activated $\mathrm{CA}_{3}$ pyramidal neurons tested was decreased to $\sim 5$ $\mathrm{Hz}$ to allow the detection of possible changes in firing activity after WAY 100635 administration in control and treated rats. On the basis of previous studies from our laboratory showing that WAY 100635 dosedependently increases the firing activity of quisqualate-activated $\mathrm{CA}_{3}$ pyramidal neurons in rats treated with the dual $5-\mathrm{HT} /$ norepinephrine reuptake inhibitor duloxetine, a dose of $100 \mu \mathrm{g} / \mathrm{kg}$ (i.v.) was chosen because it corresponds to the maximum of effect of WAY 100635 (Rueter et al., 1998).

To assess the effectiveness of the long-term treatment with paroxetine, the recovery time $50\left(R T_{50}\right)$ method was used. The $R T_{50}$ value has been shown to be a reliable index of the in vivo activity of the 5-HT reuptake process in the rat hippocampus. This value is obtained by calculating the time in seconds required for the neuron to recover $50 \%$ of its initial firing rate at the end of the microiontophoretic application of 5-HT onto a $\mathrm{CA}_{3}$ pyramidal neuron. Thus, the blockade of the 5-HT transporter by an SSRI reveals a greater $R T_{50}$ value than in controls (Piñeyro et al., 1994). The neuronal responsiveness to 5 -HT was assessed using the $I \cdot T_{50}$ method. It is the product of the current (in nanoamperes) used to eject 5-HT from the micropipette and the time (in seconds) required to obtain a $50 \%$ decrease from the baseline of the firing rate of the recorded neuron. The more sensitive a neuron is to 5 -HT, the smaller will be the
$I \cdot T 50$ value because the number of molecules ejected is proportional to the charge (de Montigny and Aghajanian, 1978).

\section{RESULTS}

\section{Effects of long-term antidepressant treatments on the responsiveness of dorsal hippocampus $\mathrm{CA}_{3}$ pyramidal neurons to 5-HT}

It has been demonstrated previously that the microiontophoretic application of 5-HT onto rat dorsal hippocampus pyramidal neurons produces a suppressant effect on their firing activity via activations of postsynaptic 5- $\mathrm{HT}_{1 \mathrm{~A}}$ receptors (Blier and de Montigny, 1987; Chaput and de Montigny, 1988). For all $\mathrm{CA}_{3}$ hippocampus pyramidal neurons tested, 5-HT $(10 \mathrm{nA})$ induced a reduction of firing activity (Figs. 1, 2; and see $4 A$ ). This inhibitory effect of 5-HT occurred without any alteration of the action potential shape and was abolished by pertussis toxin treatment (see Fig. 4C,D). Treatment with one ECS or long-term treatment with chlorpromazine, befloxatone, mirtazapine, or gepirone did not modify the suppressant effect of microiontophoretically applied 5-HT on the firing activity of $\mathrm{CA}_{3}$ pyramidal neurons. On the other hand, the treatment with seven ECSs and the long-term treatment with imipramine markedly enhanced the responsivity of $\mathrm{CA}_{3}$ pyramidal neurons to microiontophoretically applied 5-HT: the mean $I \cdot T_{50}$ value for 5 -HT was significantly lower in rats treated with seven ECS or with imipramine than in controls and rats treated with one ECS or with chlorpromazine (Fig. $3 B$ ); the $I \cdot T_{50}$ value for 5 -HT ( $5 \mathrm{nA}$ of a $2 \mathrm{~mm}$ solution) was $75 \pm 13$ $(n=16)$ in control rats, $79 \pm 12(n=14)$ in rats treated with one ECS $(t=-0.215, d f=28, p>0.8), 72 \pm 11(n=14)$ in rats treated with chlorpromazine $(t=0.147, d f=28, p>0.8), 37 \pm$ $6(n=16)$ in rats treated with seven ECSs $(t=2.57, d f=30, \mathrm{P}<$ $0.015)$, and $36 \pm 6(n=17)$ in rats treated with imipramine $(t=$ $2.71, d f=31, p<0.013)$. Moreover, the mean $R T_{50}$ value for 5 -HT was increased by $344 \%$ in paroxetine-treated rats because of the blockade of the 5-HT reuptake process (Fig. $3 A$ ). The $R T_{50}$ value for 5 -HT ( $10 \mathrm{nA}$ of a $20 \mathrm{~mm}$ solution) was $45 \pm 6 \mathrm{sec}$ in control rats $(n=7)$ and $146 \pm 7 \mathrm{sec}$ in rats treated with paroxetine $(n=7, t=-11.2, d f=12, p<0.01)$. The intravenous administration of the selective $5-\mathrm{HT}_{1 \mathrm{~A}}$ receptor antagonist WAY $100635(100 \mu \mathrm{g} / \mathrm{kg})$ significantly reduced the suppressant effect of 5-HT on $\mathrm{CA}_{3}$ pyramidal neurons in all groups. As illustrated in Figures 1 and 2, the intravenous administration of WAY 100635 significantly reduced the suppressant effect of 5-HT on the firing activity of $\mathrm{CA}_{3}$ pyramidal neurons by $52 \%$ in controls $(t=3.18$, $d f=7, p<0.01), 59 \%$ in mirtazapine-treated rats $(t=3.74, d f=$ $6, p<0.01), 62 \%$ in gepirone-treated rats $(t=7.59, d f=6, p<$ $0.01)$, and $57 \%$ in befloxatone-treated rats $(t=3.99, d f=7$, $p<0.01$.

\section{Effects of long-term antidepressant treatments on the disinhibition induced by WAY 100635}

As mentioned in Materials and Methods, the dorsal hippocampus $\mathrm{CA}_{3}$ pyramidal neurons were activated by a leak or a small current of quisqualate. In the present study, none of the treatments used significantly modified the firing activity of dorsal hippocampus $\mathrm{CA}_{3}$ pyramidal neurons (in control rats, the application of $-0.58 \pm 0.47 \mathrm{nA}$ of quisqualate resulted in a firing activity of $5.1 \pm 04 \mathrm{~Hz}, n=12$ ). In controls, the intravenous administration of WAY 100635 did not modify the firing activity of dorsal hippocampus $\mathrm{CA}_{3}$ pyramidal neurons (before: $5.1 \pm 0.4$ Hz; after WAY 100635: $4.7 \pm 0.5 \mathrm{~Hz}, n=12$ ) (Figs. $4 A, 5$ ). Similarly, in rats that received one ECS or were treated with 
A CONTROL
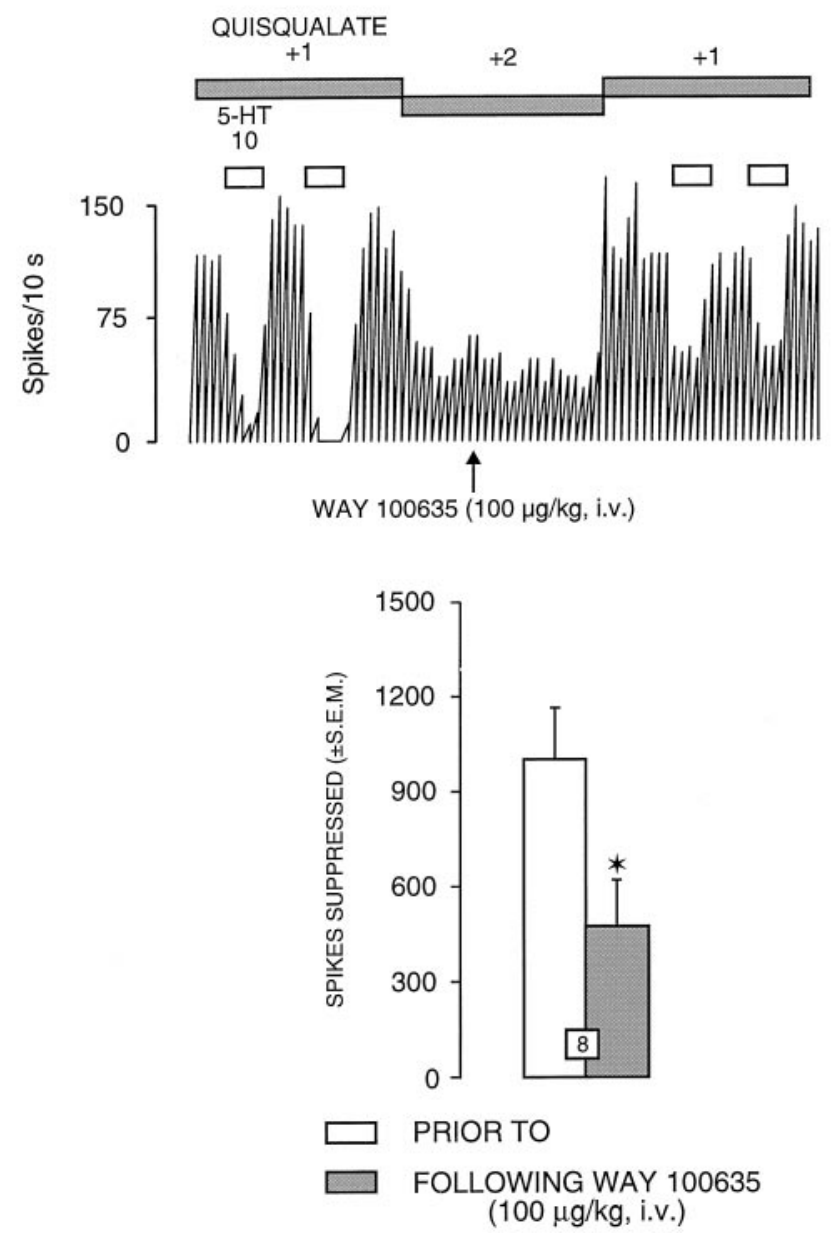

B MIRTAZAPINE $(5 \mathrm{mg} / \mathrm{kg} /$ day $\times 21$ days $)$
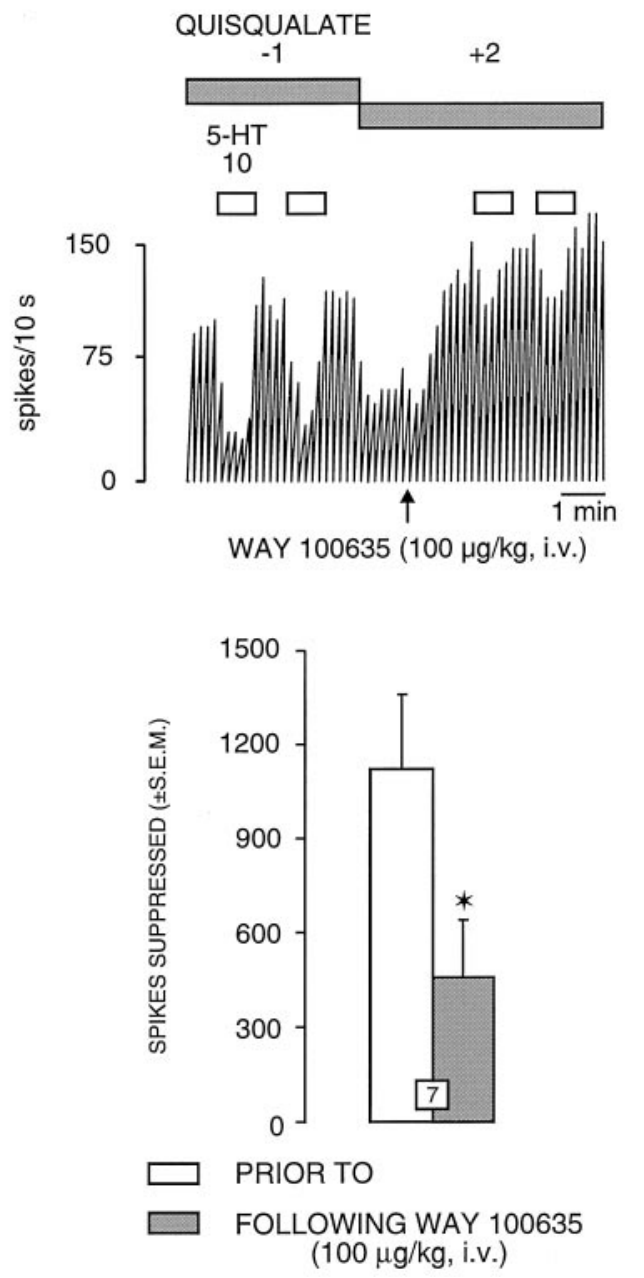

Figure 1. Integrated firing rate histogram of a dorsal hippocampus $\mathrm{CA}_{3}$ pyramidal neuron, showing its responsiveness to microiontophoretic application of 5-HT in control $(A)$ and rats treated with mirtazapine $(B)$. These neurons were activated with a quisqualate ejection current of +1 and -1 nA. Horizontal bars indicate the duration of the applications (current given in nanoamperes). Note the altered effectiveness of 5-HT to suppress firing activity after administration of WAY $100635(0.1 \mathrm{mg} / \mathrm{kg}$, i.v. $)$ in control $(A)$ and treated rats $(B)$. At the bottom of $A$ and $B$, the responsiveness to 5-HT in controls and rats treated with mirtazapine is expressed as the number of spikes suppressed per $10 \mathrm{nA}$; the number in the columns indicates the number of neurons and rats tested. ${ }^{*} p<0.01$ (paired Student's $t$ test).

chlorpromazine or pertussis toxin, the administration of WAY 100635 did not modify the firing activity of $\mathrm{CA}_{3}$ pyramidal neurons (before: $4.6 \pm 0.5 \mathrm{~Hz}$; after WAY 100635: $4.2 \pm 1 \mathrm{~Hz}$ in rats treated with one ECS, $n=8$; before: $3.9 \pm 0.5 \mathrm{~Hz}$; after WAY 100635: $3.5 \pm 0.6 \mathrm{~Hz}$ in rats treated with chlorpromazine, $n=7$; before: $4.9 \pm 0.5 \mathrm{~Hz}$; after WAY 100635: $3.8 \pm 0.3 \mathrm{~Hz}$ in rats treated with pertussis toxin, $n=6$ ) (Fig. 5). In contrast, in all other treated groups, WAY 100635 significantly increased the firing activity of dorsal hippocampus $\mathrm{CA}_{3}$ pyramidal neurons. In the groups treated with seven ECSs, imipramine, and paroxetine, the firing activity of the $\mathrm{CA}_{3}$ pyramidal neurons was markedly increased (7-ECS, before: $3.6 \pm 0.6 \mathrm{~Hz}$; after WAY 100635: $7.6 \pm$ $1 \mathrm{~Hz}, n=7$; imipramine, before: $3.7 \pm 0.6 \mathrm{~Hz}$; after WAY 100635 : $6.3 \pm 1 \mathrm{~Hz}, n=7$; paroxetine, before: $4.8 \pm 0.6 \mathrm{~Hz}$; after WAY 100635: $11.1 \pm 1.4 \mathrm{~Hz}, n=7$ ) (Figs. 4, 5). The firing activity of $\mathrm{CA}_{3}$ pyramidal neurons in groups treated with befloxatone (before: $4.2 \pm 0.5 \mathrm{~Hz}$; after WAY 100635: $8.1 \pm 0.8 \mathrm{~Hz}, n=8$ ) (Figs. $4 B, 5$ ), mirtazapine (before: $5.1 \pm 0.5 \mathrm{~Hz}$; after WAY 100635 : $8.2 \pm 0.8 \mathrm{~Hz}, n=12$ ) (Figs. $4 C, 5$ ), and gepirone (before: $5 \pm 0.8$
Hz; after WAY 100635: $15.2 \pm 2.5 \mathrm{~Hz}, n=7)($ Fig. $4 D, 5)$ was also significantly increased after the intravenous administration of WAY 100635. However, in rats treated with pertussis toxin, a 7-ECS administration failed to increase the disinhibition of $\mathrm{CA}_{3}$ pyramidal neurons induced by the intravenous administration of WAY 100635 (before: $4.8 \pm 0.5 \mathrm{~Hz}$; after WAY 100635: $3.7 \pm 0.7$ $\mathrm{Hz}, n=7$ ) (Fig. 5).

\section{DISCUSSION}

Various classes of antidepressant treatments enhance 5-HT neurotransmission with a time course consistent with their delayed therapeutic effect. Clinical evidence in support of the involvement of 5-HT is provided by the antidepressant activity of SSRIs, the long-term administration of which increases extracellular 5-HT, and also by the antidepressant activity of $5-\mathrm{HT}_{1 \mathrm{~A}}$ receptor agonists. In addition, the reduction of 5-HT levels, induced by either parachlorophenylalanine (a 5-HT synthesis inhibitor) or the dietary depletion of the 5-HT precursor L-tryptophan, reverses the antidepressant effect of several drugs, including 
A BEFLOXATONE $(0.75 \mathrm{mg} / \mathrm{kg} /$ day $\times 21$ days $)$
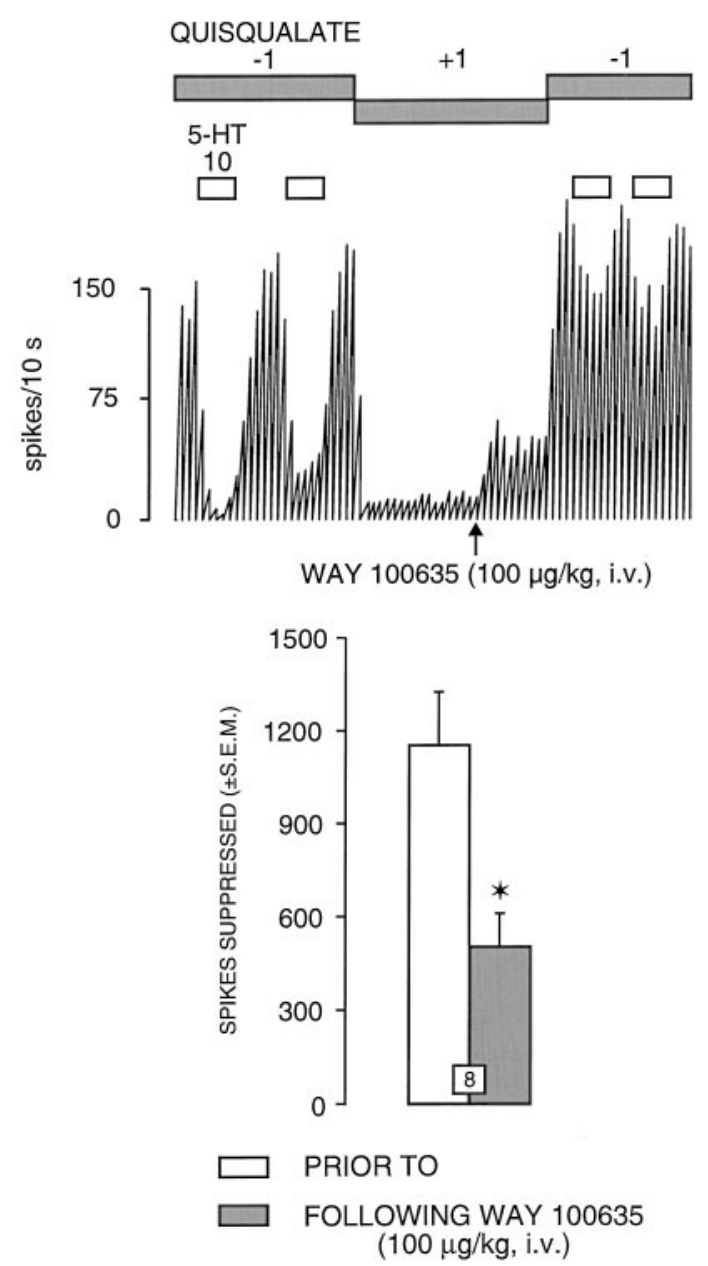

B GEPIRONE (15 mg/kg/day $x 14$ days $)$
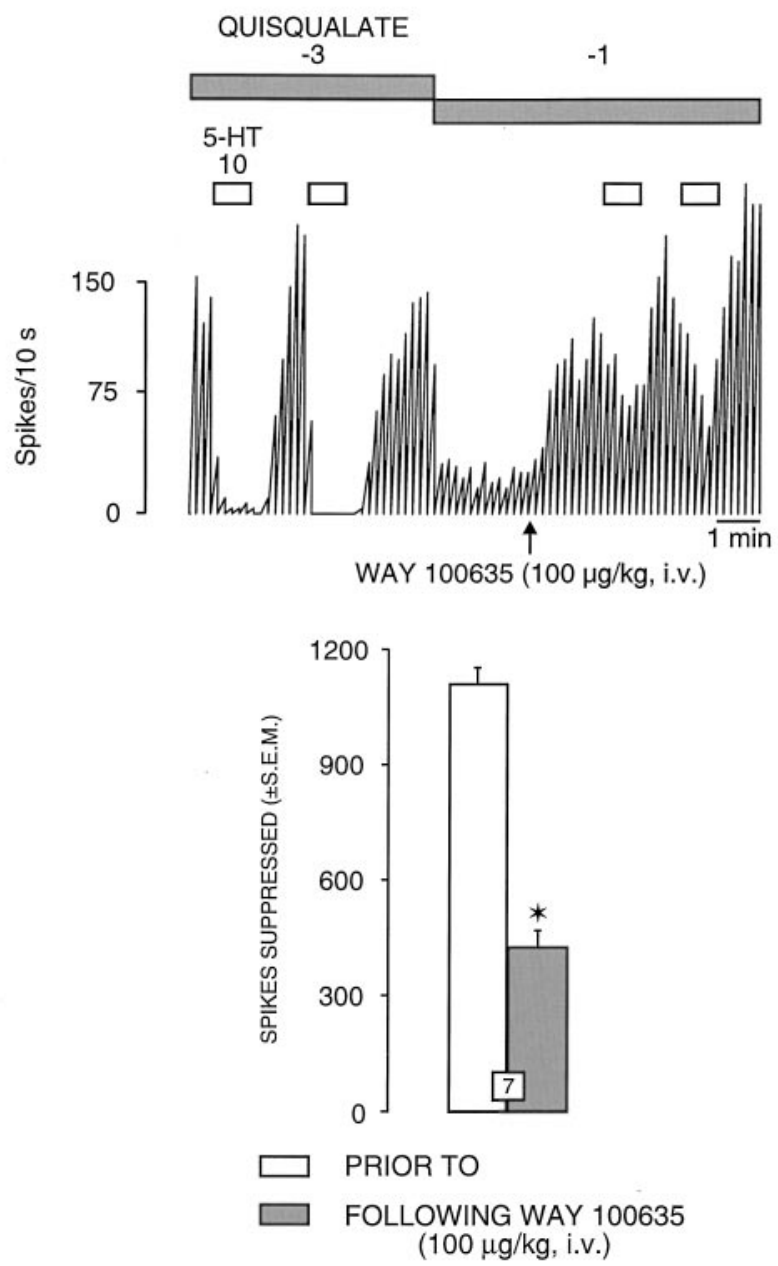

Figure 2. Integrated firing rate histogram of a dorsal hippocampus $\mathrm{CA}_{3}$ pyramidal neuron, showing its responsiveness to microiontophoretic application of 5-HT before and after the intravenous injection of WAY $100635(0.1 \mathrm{mg} / \mathrm{kg})$ in rats treated with befloxatone $(A)$ and with gepirone $(B)$. These neurons were activated with a quisqualate ejection current of -1 and $-3 \mathrm{nA}$. Horizontal bars indicate the duration of the applications (current given in nanoamperes). Note the altered effectiveness of 5-HT to suppress firing activity after administration of WAY 100635 in treated rats. At the bottom of $A$ and $B$, the responsiveness to 5-HT in rats treated with befloxatone or gepirone is expressed as the number of spikes suppressed per $10 \mathrm{nA}$; the number in the columns indicates the number of neurons and rats tested. ${ }^{*} p<0.01$ (paired Student's $t$ test).

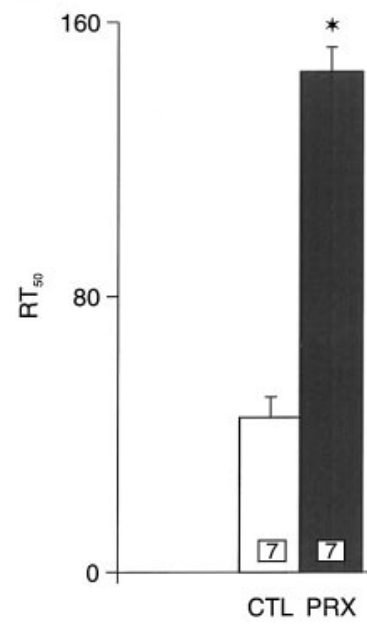

B

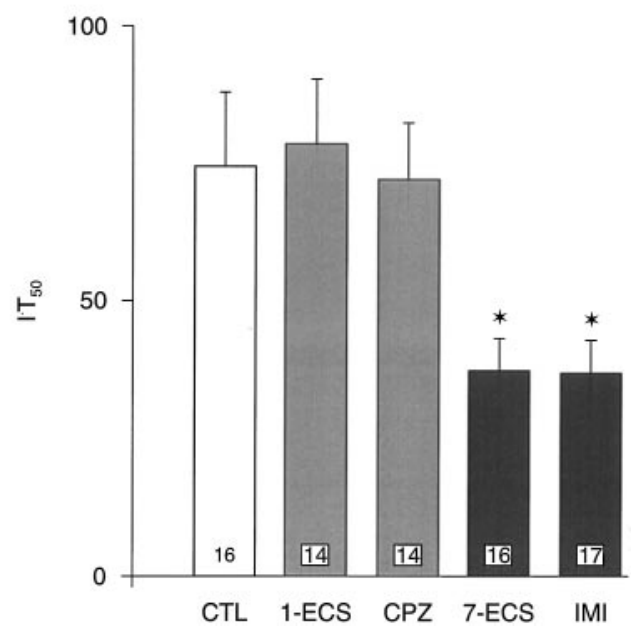

Figure 3. $A$, Recovery time, expressed as $R T_{50}$ values (means $\pm \mathrm{SEM}$ ), of dorsal hippocampus $\mathrm{CA}_{3}$ pyramidal neurons from the microiontophoretic application of 5-HT in control rats and rats treated with paroxetine for $21 \mathrm{~d}(10$ $\mathrm{mg} \cdot \mathrm{kg}^{-1} \cdot \mathrm{d}^{-1}$, s.c.). The numbers in the columns indicate the number of rats tested. ${ }^{*} p<0.05$ (unpaired Student's $t$ test). $B$, Mean ( \pm SEM) $I \cdot T_{50}$ values (see Materials and Methods) in control (CTL) and rats treated with one ECS (1-ECS), seven ECSs (7-ECS), chlorpromazine (CPZ), and imipramine $(I M I)$. The numbers in the columns indicate the number of neurons tested. ${ }^{*} p<0.05$ (unpaired Student's $t$ test). 
A ECS (7 in 14 days)

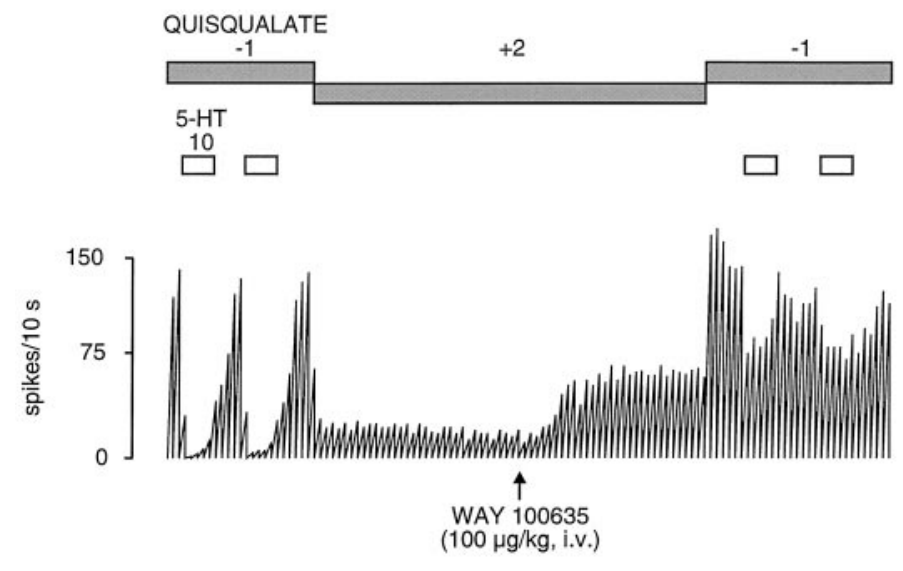

C PTX Pretreatment

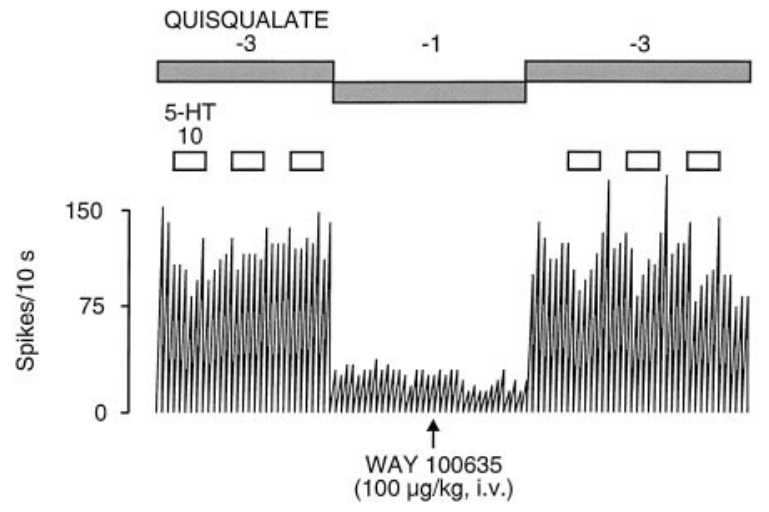

B SHAM OPERATED

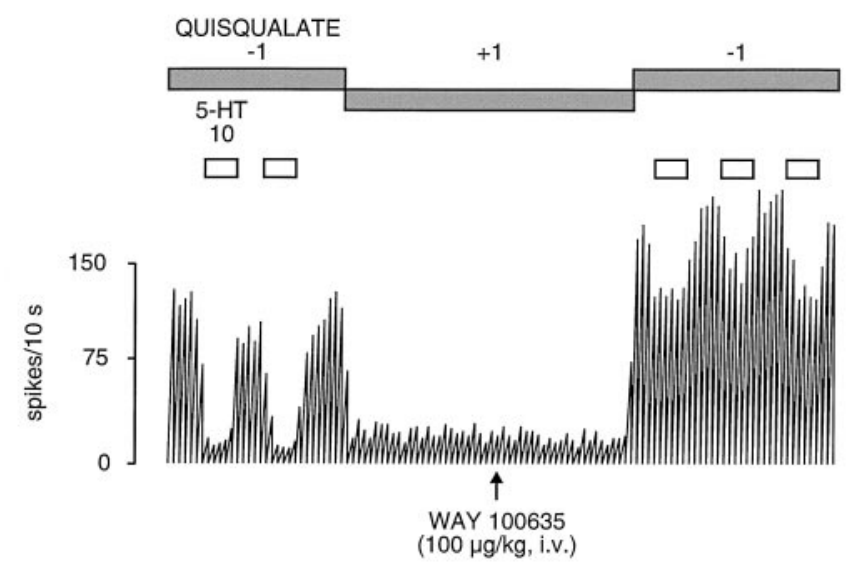

D ECS (7 in 14 days) + PTX Pretreatment

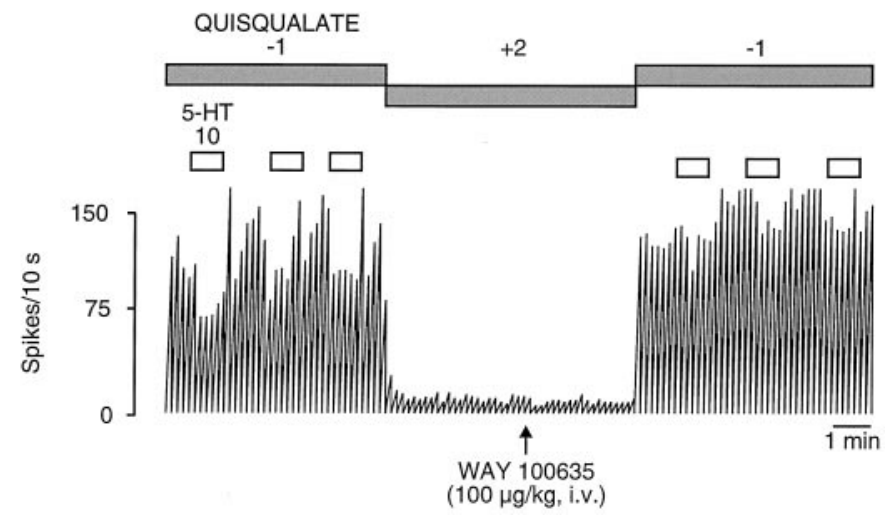

Figure 4. Integrated firing rate histograms of dorsal hippocampus $\mathrm{CA}_{3}$ pyramidal neurons showing their responsiveness to microiontophoretic application of 5-HT and to intravenous injection of WAY $100635(0.1 \mathrm{mg} / \mathrm{kg})$ in rats receiving seven ECSs $(A)$, in sham-operated rats $(B)$, in rats treated with pertussis toxin $(P T X)(C)$, and in rats receiving both 7-ECS and pertussis toxin treatments. These neurons were activated with a quisqualate ejection current of -1 to $-3 \mathrm{nA}$. Note the altered firing activity after the administration of WAY 100635 only in rats receiving seven ECSs $(A)$, and the altered suppressant effect of 5-HT in rats treated with pertussis toxin $(C, D)$.

MAOIs, TCAs, SSRIs, and mirtazapine (Shopsin et al., 1975; Delgado et al., 1990, 1997). As mentioned in the introductory remarks, preclinical evidence suggests that long-term antidepressant treatments enhance 5-HT neurotransmission via different adaptive changes [see also Blier and de Montigny (1994)]. The present electrophysiological studies show that only treatments with drugs endowed with antidepressant activity increased the tonic activation of postsynaptic $5-\mathrm{HT}_{1 \mathrm{~A}}$ receptors in the dorsal hippocampus, as evidenced by the enhancing effect of the administration of the $5-\mathrm{HT}_{1 \mathrm{~A}}$ receptor antagonist WAY 100635. These results provide the first direct functional evidence of a sustained enhancement of 5-HT neurotransmission, which seems to be a common and specific to antidepressant treatments.

Among the $5-\mathrm{HT}_{1 \mathrm{~A}}$ receptor antagonists that are available, WAY 100635 is by far the most potent and selective antagonist at both presynaptic and postsynaptic $5-\mathrm{HT}_{1 \mathrm{~A}}$ receptors (Khawaja et al., 1994; Fletcher et al., 1996). The present results indicate that WAY 100635 is indeed an effective antagonist at postsynaptic $5-\mathrm{HT}_{1 \mathrm{~A}}$ receptors, because WAY 100635 reduced the suppressant effect of microiontophoretically applied 5-HT on the firing activity of $\mathrm{CA}_{3}$ pyramidal neurons. The capacity of WAY 100635 to block the somatodendritic $5-\mathrm{HT}_{1 \mathrm{~A}}$ autoreceptor is not expected to alter its effectiveness in disinhibiting postsynaptic neurons.
Indeed, any interference would dampen this disinhibitory effect of WAY 100635, because in the presence of an SSRI in freely moving cats (Fornal et al., 1996) and of befloxatone in anesthetized rats (Haddjeri et al., 1998), WAY 100635 increases the firing of 5-HT neurons.

Treatments with ECS and TCA, studied in vivo and ex vivo, appear to sensitize postsynaptic (both intrasynaptic and extrasynaptic) 5- $\mathrm{HT}_{1 \mathrm{~A}}$ receptors (de Montigny and Aghajanian, 1978; Gallager and Bunney, 1979; de Montigny, 1984; Gravel and de Montigny, 1987; Chaput et al., 1991; Blier and Bouchard, 1992; Maj et al., 1996; Bijak et al., 1997), although negative results have been reported (Olpe and Schellenberg, 1981; Rowan and Anwyl, 1985; Beck and Halloran, 1989). Perhaps these negative results are attributable in part to the use of 5-HT as an agonist, which can also increase neuronal excitability via non-5- $\mathrm{HT}_{1 \mathrm{~A}}$ receptors such as $5-\mathrm{HT}_{2} / 5-\mathrm{HT}_{4}$ receptors (Beck, 1992; Torres et al., 1996). In the present study, long-term treatment with imipramine and seven ECSs, but not with chlorpromazine, pertussis toxin, or one ECS, significantly increased the disinhibition produced by the $5-\mathrm{HT}_{1 \mathrm{~A}}$ receptor antagonist WAY 100635, unveiling an enhancement of the tonic activation postsynaptic $5-\mathrm{HT}_{1 \mathrm{~A}}$ receptors. That this subtype of 5-HT receptor is mediating this phenomenon is supported by the observation that in rats treated with seven ECSs the 


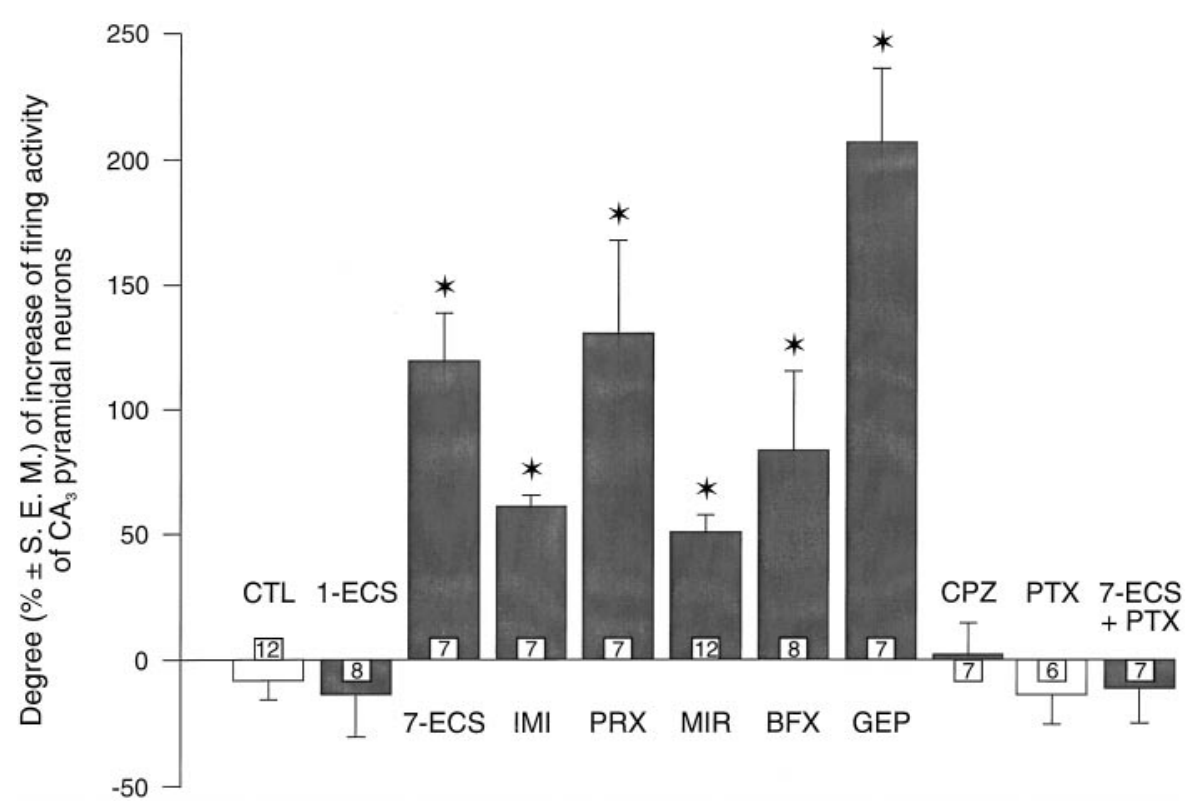

Figure 5. Changes $(\% \pm \mathrm{SEM})$ of the firing activity of quisqualate-activated dorsal hippocampus CA3 pyramidal neurons after intravenous injection of WAY $100635(100 \mu \mathrm{g} / \mathrm{kg})$ in control rats $(C T L)$ and in rats treated with imipramine (IMI, $t=-6.74, d f=17, p<0.01)$, paroxetine $(P R X$, $t=-4.71, d f=17, p<0.01)$, mirtazapine $(M I R$, $t=-5.86, d f=22, p<0.01)$, befloxatone $(B F X$, $t=-3.37, d f=18, p<0.01)$, gepirone $(G E P, t=$ $-8.95, d f=17, p<0.01)$, chlorpromazine $(C P Z$, $t=-0.77, d f=17, p>0.4)$, or pertussis toxin treatment $(P T X, t=0.44, d f=16, p>0.6)$ and receiving single $(1-E C S, t=0.34, d f=18, p>0.3)$ or multiple electroconvulsive shocks (7-ECS, $t=$ $-7.31, d f=17, p<0.01)$, or both multiple electroconvulsive shocks and pertussis toxin treatment $(7-E C S+P T X, t=0.18, d f=17, p>0.8)$. The number for each column indicates the number of rats tested. inactivation of the $\mathrm{G}_{\mathrm{i} / \mathrm{o}}$-proteins by pertussis toxin prevented it. Indeed, other hippocampal 5-HT receptors (i.e., 5- $\mathrm{HT}_{2}, 5-\mathrm{HT}_{3}$, $5-\mathrm{HT}_{4}, 5-\mathrm{HT}_{6}$, and $5-\mathrm{HT}_{7}$ receptors) are not coupled with $\mathrm{G}_{\mathrm{i} / \mathrm{o}}$-proteins.

The classes of antidepressant treatments, other than TCA and ECS, used in the present study have been shown to alter only the presynaptic component of 5-HT neurotransmission. In fact, in rats treated with paroxetine, the enhancement of the tonic activation postsynaptic $5-\mathrm{HT}_{1 \mathrm{~A}}$ receptors would be caused by an increased synaptic 5-HT concentration in the dorsal hippocampus after desensitization of somatodendritic and terminal 5-HT autoreceptors and by blockade of the neuronal 5-HT carrier (Piñeyro et al., 1994). After a $21 \mathrm{~d}$ treatment with befloxatone, the enhancement of the tonic activation of postsynaptic $5-\mathrm{HT}_{1 \mathrm{~A}}$ receptors would be caused by the increased synaptic 5-HT concentration resulting from both monoamine oxidase-A (MAO-A) inhibition and desensitization of $\alpha_{2}$-adrenoceptors on 5-HT nerve terminals (Blier and Bouchard, 1994; Mongeau et al., 1994). A similar enhancement of tonic $5-\mathrm{HT}_{1 \mathrm{~A}}$ receptor activation would result from repeated administration of mirtazapine, in this case as a result of a sustained increase in the activity of 5-HT neurons accompanied by a desensitization of $\alpha_{2}$-adrenoceptor (Haddjeri et al., 1997). Finally, it has been shown that gepirone treatment desensitized the presynaptic $5-\mathrm{HT}_{1 \mathrm{~A}}$ autoreceptors on 5-HT neurons, but not the postsynaptic $5-\mathrm{HT}_{1 \mathrm{~A}}$ receptors on $\mathrm{CA}_{3}$ pyramidal neurons (Blier and de Montigny, 1987). Therefore, it was hypothesized that such a treatment might result in an increase of 5-HT neurotransmission, but it must be noted that, at the time, selective $5-\mathrm{HT}_{1 \mathrm{~A}}$ receptor antagonists were not available to test this hypothesis. In the present study, the intravenous administration of WAY 100635 significantly increased the firing activity of $\mathrm{CA}_{3}$ pyramidal neurons in rats treated with gepirone, whose 5-HT neurons have regained their normal firing activity, thus showing that the blockade of the postsynaptic $5-\mathrm{HT}_{1 \mathrm{~A}}$ receptors by WAY 100635 unveils an enhancement of their tonic activation.

Serotonin receptors other than those of the 5-HT $\mathrm{HA}_{1 \mathrm{~A}}$ subtype may also be involved in the antidepressant response. Indeed, it has been demonstrated that some postsynaptic 5-HT receptors, other than the 5-HT $\mathrm{HA}_{1 \mathrm{~A}}$ subtype, become sensitized after longterm antidepressant treatments. For instance, repeated TCA ad- ministration sensitizes postsynaptic $5-\mathrm{HT}_{2}$ receptors in the facial motor nucleus and a yet uncharacterized 5-HT receptor subtype in the amygdala (Menkes et al., 1980; Wang and Aghajanian, 1980).

In conclusion, the present electrophysiological studies show that chronic treatment with the TCA imipramine, the SSRI paroxetine, the selective and reversible MAO-A befloxatone, the $\alpha_{2}$-adrenergic antagonist mirtazapine, or the $5-\mathrm{HT}_{1 \mathrm{~A}}$ receptor agonist gepirone, as well as repeated ECS therapy, enhanced the tonic activation of postsynaptic $5-\mathrm{HT}_{1 \mathrm{~A}}$ receptors in the dorsal hippocampus, as shown by the disinhibition produced by the selective $5-\mathrm{HT}_{1 \mathrm{~A}}$ receptor antagonist WAY 100635. These results constitute novel direct evidence that an enhanced 5-HT neurotransmission may underlie the antidepressant response in humans.

\section{REFERENCES}

Beck SG (1992) 5-Hydroxytryptamine increases excitability of CA1 hippocampal pyramidal cells. Synapse 10:334-340.

Beck SG, Halloran PM (1989) Imipramine alters beta-adrenergic, but not serotonergic, mediated responses in rat hippocampal pyramidal cells. Brain Res 504:72-81.

Bel N, Artigas F (1993) Chronic treatment with fluvoxamine increases extracellular serotonin in frontal cortex but not in raphe nuclei. Synapse $15: 243-245$.

Bijak M, Tokarski K, Maj J (1997) Repeated treatment with antidepressant drugs induces subsensitivity to the excitatory effect of 5-HT4 receptor activation in the rat. Naunyn Schmiedebergs Arch Pharmacol 355:14-19.

Blier P, Bouchard C (1992) Effect of repeated electroconvulsive shocks on serotonergic neurons. Eur J Pharmacol 211:365-373.

Blier P, Bouchard C (1994) Modulation of 5-HT release in guinea-pig brain following long-term administration of antidepressant drugs. Br J Pharmacol 113:485-495.

Blier P, de Montigny C (1987) Modification of 5-HT neuron properties by sustained administration of the $5-\mathrm{HT}_{1 \mathrm{~A}}$ agonist gepirone: electrophysiological studies in the rat brain. Synapse 1:470-480.

Blier P, de Montigny C (1994) Current advances and trends in the treatment of depression. Trends Pharmacol Sci 15:220-226.

Blier P, de Montigny C (1985) Serotoninergic but not noradrenergic neurons in rat central nervous system adapt to long-term treatment with monoamine oxidase inhibitors. Neuroscience 16:949-955.

Blier P, Lista A, de Montigny C (1993) Differential properties of preand postsynaptic 5-hydroxytryptamine1A receptors in the dorsal and 
hippocampus: II. Effect of pertussis and cholera toxins. J Pharmacol Exp Ther 265:16-23.

Burnet PWJ, Michelson D, Smith MA, Gold PW, Sternberg EM (1994) The effect of chronic imipramine administration on the densities of $5-\mathrm{HT}_{1 \mathrm{~A}}$ and $5-\mathrm{HT}_{2}$ receptors and the abundances of 5-HT receptor and transporter mRNA in the cortex, hippocampus and dorsal raphe of three strains of rat. Brain Res 638:311-313.

Chaput Y, de Montigny C (1988) Effects of the 5-HT1 receptor antagonist BMY 7378 on the 5-HT neurotransmission: electrophysiological studies in the rat central nervous system. J Pharmacol Exp Ther 246:359-370.

Chaput Y, Blier P, de Montigny C (1988) Acute and long-term effects of antidepressant 5-HT reuptake blockers on the efficacy of 5-HT neurotransmission: electrophysiological studies in the rat CNS. Adv Biol Psychiatry 17:1-17.

Chaput Y, de Montigny C, Blier P (1991) Presynaptic and postsynaptic modifications of the serotonin system by long-term administration of antidepressant treatments: an in vivo electrophysiologic study in the rat. Neuropsychopharmacology 5:219-229.

Cummings JL (1993) The neuroanatomy of depression. J Clin Psychiatry 543:14-20.

Delgado PL, Miller MLL, Salomon RM, Van Vilthoven V, Heninger GR, Charney DS (1990) Serotonin function and the mechanism of antidepressant action: reversal of antidepressant-induced remission by rapid depletion of plasma tryptophan. Arch Gen Psychiatry 47:411-418.

Delgado PL, Moreno F, Gelenberg AJ, Potter R (1997) Sequential catecholamine and 5-HT depletion in mirtazapine-treated depressives. Am Coll Neuropsychopharmacol 33:144.

de Montigny C (1984) Electroconvulsive treatments enhance responsiveness of forebrain neurons to serotonin. J Pharmacol Exp Ther 228:230-234.

de Montigny C, Aghajanian GK (1978) Tricyclic antidepressants: longterm treatment increases responsivity of rat forebrain neurons to serotonin. Science 202:1303-1306.

Fletcher A, Forster EA, Bill DJ, Brown G, Cliffe IA, Hartley JE, Jones DE, McLenachan A, Stanhope KJ, Critchley DJ, Childs KJ, Middlefell VC, Lanfumey L, Corradetti R, Laporte AM, Gozlan H, Hamon M, Dourish CT (1996) Electrophysiological, biochemical, neurohormonal and behavioural studies with WAY-100635, a potent, selective and silent 5-HT1A receptor antagonist. Behav Brain Res 73:337-353.

Fornal CA, Metzler CW, Gallegos RA, Veasey SC, McCreary AC, Jacobs BL (1996) WAY-100635, a potent and selective 5-hydroxytryptamine $1 \mathrm{~A}$ antagonist, increases serotonergic activity in behaving cats: comparison with $(S)$-WAY-100135. J Pharmacol Exp Ther 278: $752-762$.

Gallager DW, Bunney Jr WE (1979) Failure of chronic lithium treatment to block tricyclic antidepressant-induced 5-HT supersensitivity. Naunyn Schmiedebergs Arch Pharmacol 307:129-133.

Gravel P, de Montigny C (1987) Noradrenergic denervation prevents sensitization of rat forebrain neurons to serotonin by tricyclic antidepressant treatment. Synapse 1:233-239.

Haddjeri N, Blier P, de Montigny C (1997) Effect of long-term treatment with the $\alpha_{2}$-adrenoceptor antagonist mirtazapine on 5-HT neurotransmission. Naunyn Schmiedebergs Arch Pharmacol 354:1-10.

Haddjeri N, de Montigny C, Curet O, Blier P (1998) Effect of the reversible monoamine oxidase-A inhibitor befloxatone on the rat 5-HT neurotransmission. Eur J Pharmacol 243:179-192

Haigler HJ, Aghajanian GK (1974) Lysergic acid diethylamide and serotonin: a comparison of effects on serotonergic neurons and neurons receiving a serotonergic input. J Pharmacol Exp Ther 188:688-699.

Heninger GR, Charney DS (1987) Mechanisms of action of antidepressant treatments: implications for the etiology and treatment of depression disorders. In: Psychopharmacology: the third generation of progress (Meltzer HY, ed), pp 535-544. New York: Raven.

Kandel ER, Spencer WA (1961) Electrophysiology of hippocampal neu- rons. II. After potentials and repetitive firing. J Neurophysiol 24:243-259.

Khawaja X, Evans N, Reilly Y, Ennis C, Minchin MCW (1994) Characterisation of the binding of $\left[{ }^{3} \mathrm{H}\right] \mathrm{WAY} 100635$, a novel 5-hydroxytryptamine ${ }_{1 \mathrm{~A}}$ receptor antagonist, to the rat. J Neurochem 64:2716-2726.

Maes M, Meltzer HY (1995) The serotonin hypothesis of major depression. In: Psychopharmacology: the fourth generation of progress (Bloom FE, Kupfer DJ, eds), pp 933-944. New York: Raven.

Maj J, Bijak M, Dziedzicka-Wasylewska M, Rogoz R, Rogoz Z, Skuza G, Tokarski T (1996) The effects of paroxetine given repeatedly on the 5 -HT receptor subpopulations in the rat brain. Psychopharmacology 127:73-82.

Menkes DB, Aghajanian GK, McCall RB (1980) Chronic antidepressant treatment enhances $\alpha$-adrenergic and serotonergic responses in the facial nucleus. Life Sci 27:45-55.

Mongeau R, de Montigny C, Blier P (1994) Electrophysiologic evidence for desensitisation of $\alpha_{2}$-adrenoceptors on serotonin terminals following long-term treatment with drugs increasing norepinephrine synaptic concentration. Neuropsychopharmacology 10:41-51.

Nowak G, Dulinski J (1991) Effect of repeated treatment with electroconvulsive shock (ECS) on serotonin receptor density and turnover in the rat cerebral cortex. Pharmacol Biochem Behav 38:691-694.

Olpe HR, Schellenberg A (1981) The sensitivity of cortical neurons to serotonin: effect of chronic treatment with antidepressants, serotoninuptake inhibitors and monoamine-oxidase-blocking drugs. J Neural Transm 51:233-244.

Piñeyro G, Blier P, Dennis T, de Montigny C (1994) Desensitization of the neuronal 5-HT carrier following its long-term blockade. J Neurosci 14:3036-3047.

Price LH, Charney DS, Delgado PL (1990) Clinical data on the role of serotonin in the mechanism(s) of action of antidepressant drug. J Clin Psychiatry 51:44-50.

Ranck JB (1975) Behavioral correlates and firing repertoires of neurons in the dorsal hippocampal formation and septum of unrestrained rats. In: The hippocampus (Isaacson RL, Pribram KH, eds), pp 207-244. New York: Plenum.

Rowan MJ, Anwyl R (1985) The effect of prolonged treatment with tricyclic antidepressants on the actions of 5-hydroxytryptamine in the hippocampal slice of the rat. Neuropharmacology 24:131-137.

Rueter L, de Montigny C, Blier P (1998) Electrophysiological characterization of the effect of long-term duloxotine administration on serotonergic and noradrenergic systems. J Pharmacol Exp Ther 285:404-412.

Shopsin B, Gershon S, Golstein M (1975) The use of synthesis inhibitors in defining a role for biogenic amines during imipramine treatment in depressed patients. Psychopharmacol Commun 1:239-249.

Stockmeier CA, Wingenfeld P, Gudelski GA (1992) Effects of repeated electroconvulsive shock on serotonin sA $_{\mathrm{A}}$ receptor binding and receptormediated hypothermia in the rat. Neuropharmacology 31:1089-1094.

Torres GE, Arfken CL, Andrade R (1996) 5-Hydroxytryptamine4 receptors reduce afterhyperpolarization in hippocampus by inhibiting calcium-induced calcium release. Mol Pharmacol 50:1316-1322.

Van Praag HM, Asnis GM, Khan RS (1990) Monoamines and abnormal behaviour: a multiaminergic perspective. Br J Psychiatry 157:723-734.

Wang RY, Aghajanian GK (1980) Enhanced sensitivity of amygdaloid neurons to serotonin and norepinephrine by antidepressant treatments. Commun Psychopharmacol 4:83-90.

Welner SA, de Montigny C, Desroches J, Desjardins P, Suranyi-Cadotte BE (1989) Autoradiographic quantification of serotonin sA $_{1 \mathrm{~A}}$ receptors in rat brain following antidepressant drug treatment. Synapse 4:347-352.

Yoshioka M, Matsumoto M, Numazawa R, Togashi H, Smith CB, Saito H (1995) Changes in the regulation of 5-hydroxytryptamine release by alpha2-adrenoceptors in the rat hippocampus after long-term desipramine treatment. Eur J Pharmacol 294:565-570. 